\title{
Effects of sodium sesquicarbonate on dry matter intake and production of milk and milk components by Holstein cows
}

\author{
J. H. Clark, ${ }^{* 1}$ R. A. Christensen, ${ }^{* 2}$ H. G. Bateman II, ${ }^{* 3}$ and K. R. Cummings $\dagger$ \\ *Department of Animal Sciences, University of Illinois, Urbana 61801 \\ †Church \& Dwight Company, Princeton, NJ 08543-5297
}

\begin{abstract}
Forty-six multiparous Holstein cows were used to investigate the effects of sodium sesquicarbonate on dry matter intake, body weight, and production and composition of milk during a 308-d lactation. Diets contained alfalfa silage, corn silage, and concentrate. Composition of diets was changed twice during the 308d lactation experiment. Diets fed during d 1 to 175 and d 176 to 245 were formulated to contain more rumenundegradable protein and fat, and less forage than that fed during d 246 to 308 . Sodium sesquicarbonate did not affect yields of milk, $4 \%$ fat-corrected milk, and components in milk, or percentages of components in milk during the complete 308-d lactation or during d 1 to 175 or d 176 to 245 . However, from d 246 to 308 , cows fed sodium sesquicarbonate produced more milk, $4 \%$ fat-corrected milk, fat, protein, and solids-not-fat than did control cows. Milk composition was not altered. These data suggest that composition of the diet has a significant effect on the response to dietary buffers by lactating dairy cows.
\end{abstract}

Key words: sodium sesquicarbonate, buffer, dairy cow

\section{INTRODUCTION}

Dietary buffers are routinely used to alleviate or prevent metabolic disorders that are associated with the consumption of high concentrate diets by dairy cows. Results are variable, and the effectiveness of added buffers appears to be dependent on the inherent buffering capacity of the basal diet. Positive responses in DMI and productivity are most often observed for cows fed diets that are low in effective fiber (Erdman, 1988). Buffers appear to modify the ruminal environment by

Received December 22, 2008.

Accepted February 21, 2009.

${ }^{1}$ Corresponding author: jhclark@uiuc.edu

${ }^{2}$ Current address: FDA/Center for Veterinary Medicine, Rockville, MD 20855.

${ }^{3}$ Current address: Akey, PO Box 5002, Lewisburg, OH 45338. maintaining $\mathrm{pH}$ within an optimal range and by increasing the dilution rate of ruminal fluid (Davis, 1979; Okeke et al., 1983).

Sodium sesquicarbonate $\left(\mathrm{NaHCO}_{3} \cdot \mathrm{Na}_{2} \mathrm{CO}_{3} \cdot 2 \mathrm{H}_{2} \mathrm{O}\right.$; NaSC) and $\mathrm{NaHCO}_{3}$ are both Trona ore derivates that possess the potential to neutralize acids in the rumen. Utilization of $\mathrm{NaHCO}_{3}$ as a dietary buffer is well documented. Sodium bicarbonate increased DMI (Erdman et al., 1980; Kilmer et al., 1980, 1981; Rogers et al., 1985), milk fat percentage (Erdman et al., 1982), and milk fat yield (Kilmer et al., 1980; Rogers et al., 1985) of cows during early lactation when they were fed corn silage as the major source of forage. Research utilizing NaSC as a dietary buffer is limited but indicates that $\mathrm{NaSC}$ and $\mathrm{NaHCO}_{3}$ are equally effective as buffers in the rumen (Aguilar and Jordan, 1985; Poos-Floyd and Coyle, 1986; Ghorbani et al., 1989; Solorzano et al., 1989); however, responses in DMI, yields of milk and milk components, and milk composition have been variable in short-term continuous or switch-over experiments (Donker and Marx, 1980; Aguilar and Jordan, 1985; Jordan and Aguilar, 1985; Poos-Floyd et al., 1985; Poos-Floyd and Coyle, 1986; Cassida et al., 1988; Ghorbani et al., 1989; Solorzano et al., 1989). Only one long-term experiment (Tucker et al., 1994) has been conducted using NaSC. The objectives of this experiment were to investigate the effects of NaSC on DMI, production and composition of milk, BW, and BCS of Holstein cows during a complete 308-d lactation.

\section{MATERIALS AND METHODS}

The experiment was conducted according to procedures of the University of Illinois Laboratory Animal Care Advisory Committee.

\section{Cows, Treatments, and Experimental Design}

Forty-six multiparous Holstein cows were used in a 308-d lactation experiment. Approximately $7 \mathrm{~d}$ before expected calving, cows were moved into individual maternity stalls. One kilogram of the early lactation diet that contained $\mathrm{NaSC}$, Ca salts of long-chain fatty 
Table 1. Ingredient and chemical composition of total mixed diets (DM basis)

\begin{tabular}{|c|c|c|c|c|c|c|}
\hline \multirow[b]{3}{*}{ Composition } & \multicolumn{6}{|c|}{ Days of lactation } \\
\hline & \multicolumn{2}{|c|}{1 to 175} & \multicolumn{2}{|c|}{176 to 245} & \multicolumn{2}{|c|}{246 to 308} \\
\hline & Control & $\mathrm{NaSC}^{1}$ & Control & $\mathrm{NaSC}$ & Control & $\mathrm{NaSC}$ \\
\hline \multicolumn{7}{|l|}{ Ingredient, \% } \\
\hline Alfalfa silage & 25.0 & 25.0 & 25.0 & 25.0 & 35.0 & 35.0 \\
\hline Corn silage & 20.0 & 20.0 & 20.0 & 20.0 & 25.0 & 25.0 \\
\hline Whole soybeans & 10.0 & 10.0 & 5.0 & 5.0 & - & - \\
\hline Ground shelled corn & 26.8 & 25.8 & 32.7 & 31.7 & 26.1 & 25.3 \\
\hline Blood meal & 1.0 & 1.0 & - & - & - & - \\
\hline Soybean meal (49\% CP) & 5.0 & 5.0 & 7.0 & 7.0 & 5.6 & 5.6 \\
\hline Distillers grains with solubles & 5.0 & 5.0 & 5.0 & 5.0 & 4.0 & 4.0 \\
\hline Fat $^{2}$ & 1.8 & 1.8 & - & - & - & - \\
\hline Soybean hulls & 3.0 & 3.0 & 3.0 & 3.0 & 2.4 & 2.4 \\
\hline Sodium chloride & 0.30 & 0.30 & 0.31 & 0.31 & 0.25 & 0.25 \\
\hline Vitamin/mineral $\operatorname{mix}^{3}$ & 0.15 & 0.15 & 0.15 & 0.15 & 0.12 & 0.12 \\
\hline $\mathrm{NaSC}$ & - & 1.00 & - & 1.00 & - & 0.80 \\
\hline Dicalcium phosphate & 0.60 & 0.60 & 0.45 & 0.45 & 0.36 & 0.36 \\
\hline Magnesium oxide & 0.20 & 0.20 & 0.12 & 0.12 & 0.10 & 0.10 \\
\hline Sodium sulfate & 0.35 & 0.35 & 0.32 & 0.32 & 0.26 & 0.26 \\
\hline Limestone & 0.80 & 0.80 & 0.99 & 0.99 & 0.79 & 0.79 \\
\hline \multicolumn{7}{|l|}{ Nutrient } \\
\hline DM & 61.4 & 62.8 & 62.6 & 62.3 & 58.7 & 59.1 \\
\hline $\mathrm{CP}$ & 18.4 & 18.3 & 16.9 & 16.6 & 15.5 & 15.4 \\
\hline $\mathrm{ADF}$ & 19.5 & 19.8 & 19.2 & 18.8 & 23.1 & 22.7 \\
\hline $\mathrm{NDF}$ & 30.2 & 29.9 & 27.9 & 27.5 & 33.1 & 32.9 \\
\hline
\end{tabular}

${ }^{1} \mathrm{NaSC}=$ sodium sesquicarbonate.

${ }^{2}$ Ca salts of palm fatty acids marketed as Megalac (Church \& Dwight Co., Princeton, NJ).

${ }^{3}$ Contained $0.004 \% \mathrm{Co}, 0.5 \% \mathrm{Cu}, 0.025 \% \mathrm{I}, 2.0 \% \mathrm{Fe}, 5.0 \% \mathrm{Mg}, 3.0 \% \mathrm{Mn}, 7.5 \% \mathrm{~K}, 0.015 \% \mathrm{Se}, 10.0 \% \mathrm{~S}, 3.0 \%$

$\mathrm{Zn}, 2,200 \mathrm{IU}$ of vitamin $\mathrm{A} / \mathrm{g}, 660 \mathrm{IU}$ of vitamin $\mathrm{D}_{3} / \mathrm{g}$, and $8 \mathrm{IU}$ of vitamin $\mathrm{E} / \mathrm{g}$.

acids (Megalac, Church \& Dwight Co., Princeton, NJ), distillers grains with solubles, and blood meal (Table 1) was mixed into a standard diet for prepartum cows and fed until parturition so that cows could adapt to these dietary ingredients, even though this is not a normal recommended practice for feeding nonlactating cows.

One day after parturition, cows were moved into individual tie stalls. The experiment was divided into 3 periods according to stage of lactation. Periods were $\mathrm{d}$ 1 to 175 , d 176 to 245 , and d 246 to 308 postcalving. At the time of calving, cows were assigned to a control diet or a diet that contained NaSC (Table 1) in a randomized design. Cows were fed $2 \mathrm{~kg}$ of alfalfa-bromegrass hay plus their respective TMR per day for the first 7 $\mathrm{d}$ postcalving. Ingredient and nutrient composition of diets fed during the 3 periods are shown in Table 1 .

During d 1 to 175, the forage to concentrate ratio of the diets was 45:55. Blood meal and dried distillers grains with solubles were included in the diet as sources of RUP. Fat was supplied as whole raw soybeans $(10 \%$ of DM) and Ca salts of palm oil fatty acids (1.8\% of $\mathrm{DM}$ ). These diets supplied about $3.5 \%$ fat above the basal ingredient levels on a DM basis from whole raw soybeans and $\mathrm{Ca}$ salts of long-chain fatty acids. The NaSC was included in the diet as $1 \%$ of the DM.
A 50:50 mixture (DM basis) of either the control or NaSC diets fed during d 1 to 175 and d 176 to 245 of lactation (Table 1) was fed for $6 \mathrm{~d}$ beginning on $\mathrm{d} 176$ of lactation to transition cows to diets fed until d 246 of lactation. During d 184 to 245, the energy content of the diet was decreased by replacing one-half of the whole raw soybeans and all of the Ca salts of long-chain fatty acids with corn grain. The CP content of the diet was decreased by removing blood meal from the diet. The forage to concentrate ratio (45:55) and the NaSC percentage $(1 \%)$ of the diet were the same as for diets fed during d 1 to 175 .

During d 246 to 308, the energy content of the diet was decreased more by removing all of the whole raw soybeans, and a portion of the corn and soybean meal. The concentration of forage in the diet was increased to $60 \%$ of the dietary DM. The percentage of NaSC in the diet was decreased from 1.0 to $0.8 \%$ of the DM.

\section{DMI, Milk Production and Composition, BW, and BCS}

All TMR were fed for ad libitum intake twice daily at 1000 and $1600 \mathrm{~h}$ to meet stated nutrient requirements (NRC, 1989). Orts were weighed and recorded daily before the $1000 \mathrm{~h}$ feeding. Samples of forages, whole 
raw soybeans, and concentrate mixtures were taken weekly and a portion was analyzed for $\mathrm{DM}\left(100^{\circ} \mathrm{C}\right.$ for $24 \mathrm{~h}$ ) to use for adjusting the feeding regimen, and the remainder was frozen $\left(-20^{\circ} \mathrm{C}\right)$. Individual samples of alfalfa haylage, corn silage, whole raw soybeans, and concentrate mixtures were thawed, composited on an equal wet weight basis at 4-wk intervals, and analyzed for DM, CP, ADF, and NDF using wet chemistry techniques (Dairy One Forage Laboratory, Ithaca, NY). Crude protein was assayed using block digestion and a Tecator Kjeltec 2400 analyzer (Foss, Eden Prairie, MN) with automatic distillation and titration. Acid detergent fiber and NDF were assayed using techniques described by AOAC (2002) and Van Soest et al. (1991), respectively. Samples of TMR were taken weekly and analyzed for DM content $\left(100^{\circ} \mathrm{C}\right.$ for $\left.24 \mathrm{~h}\right)$. The DM from the TMR and the DM refused in orts were used to calculate DMI.

Cows were milked twice daily at 0430 and $1530 \mathrm{~h}$, and the milk yield of individual cows was recorded at each milking. Milk was sampled weekly from 2 consecutive milkings, preserved with 2-bromo-2-nitropropane1,3-diol. Milk samples were warmed to disperse fat and composited according to milk yield. Composited samples were analyzed for contents of fat and CP by infrared analysis (Dairy Lab Services Inc., Dubuque, IA) and SNF (Golding, 1959).

Cows were weighed within $12 \mathrm{~h}$ of calving and weekly immediately after the morning milking for the remainder of the experiment. The BCS were taken before calving, 1 wk after calving, and at 2-wk intervals for the remainder of the experiment. Cows were scored by 3 individuals using a 5 -point scale with 0.5 -unit increments $(1=$ thin to $5=$ fat; Wildman et al., 1982). The 3 scores were averaged to determine a composite BCS for each cow. When individual scores for a cow varied by 0.75 units or more, the cow was rescored and the mean of the second scores was used.

\section{Statistical Analyses}

Data from 3 cows were not used in the statistical analyses. Two cows were removed from the NaSC treatment and 1 cow was removed from the control treatment because of mastitis and a teat injury. Ten cows ( 7 fed the control diet and 3 fed the NaSC diet) were removed from the experiment before completing $308 \mathrm{~d}$ of lactation to allow for a normal dry period because they conceived soon after calving. Five other cows were removed early from treatment ( 3 fed the control diet, and 2 fed the NaSC diet) because of low milk production. These 15 cows were removed from treatment, on average, $21 \mathrm{~d}$ before completion of the 308-d lactation experiment. Data collected from these 15 cows before removal from the experiment were included in the data set used for statistical analyses.

All data were reduced to weekly means before statistical analyses. Data were analyzed as a split plot in time design with treatments as whole plots and week as subplots using the Mixed Models procedure of SAS (Littell et al., 1996). Fixed effects in the model included treatment, week, and the interaction of treatment and week. Random effects in the model were cow nested within treatment (whole-plot error) and residual error (subplot error). Week was modeled as repeated measures using the autoregressive order one covariance structure. Because cows fed the diet that contained NaSC required more days on average before conception than did control cows, the number of days open was tested as a covariate for whole plots. Days open was found to be nonsignificant $(P>0.2$ in all cases) and was dropped from further analysis. Data are presented as least squares means. These data were divided into periods corresponding with diet changes (d 1 to 175 ; d 176 to 245 ; d 246 to 308 ) and analyzed within each period using the same model as used on the full data set. Because days open were found to be nonsignificant when analyzing the data for the entire lactation, days open were not used as a covariate when analyzing within a dietary period. Because of missing observations within the data set, pooled SEM differed between the treatments. The pooled SEM that are reported were calculated as residual error divided by the square root of the number of observations used in the analysis. Actual probability values are shown for the main treatment effect.

\section{RESULTS AND DISCUSSION}

During the complete 308-d lactation experiment, the addition of NaSC to the diet did not affect yields of milk, $4 \% \mathrm{FCM}$, fat, protein, and SNF or percentages of fat, protein, and SNF in milk (Table 2). Milk yield of all cows in this experiment averaged $31.6 \mathrm{~kg} / \mathrm{d}$ and the milk contained $3.53 \%$ fat, $3.10 \%$ protein, and $7.94 \%$ SNF. The addition of NaSC to the diet did not affect DMI or DMI as a percentage of BW (Table 2) or BW and BCS (Table 3) during the complete 308-d lactation experiment. These data are in agreement with results of other experiments that showed DMI (Jordan and Aguilar, 1985; Poos-Floyd et al., 1985; Coppock et al., 1986; Cassida et al., 1988), milk yield (Jordan and Aguilar, 1985; Poos-Floyd et al., 1985; Cassida et al., 1988; Ghorbani et al., 1989; Solorzano et al., 1989), FCM yield (Poos-Floyd and Coyle, 1986; Solorzano et al., 1989), fat percentage (Jordan and Aguilar 1985), and protein percentage (Coppock et al., 1986; Cassida et al., 1988; Ghorbani et al., 1989; Solorzano et al., 1989) 
Table 2. Least squares means for DMI and milk production and composition for a complete 308-d lactation for cows fed diets without (control) or with sodium sesquicarbonate (NaSC)

\begin{tabular}{lcccc}
\hline & \multicolumn{2}{c}{ Treatment } & & \\
\cline { 2 - 3 } Item & Control & NaSC & SEM & $P<\mathrm{F}$ \\
\hline $\mathrm{DMI}, \mathrm{kg} / \mathrm{d}$ & 21.1 & 21.2 & 0.21 & 0.89 \\
$\mathrm{DMI}, \%$ of BW & 3.18 & 3.33 & 0.005 & 0.22 \\
Milk, kg/d & 31.0 & 32.2 & 0.38 & 0.35 \\
$4 \% \mathrm{FCM}, \mathrm{kg} / \mathrm{d}$ & 28.4 & 29.9 & 0.208 & 0.20 \\
Milk fat, \% & 3.48 & 3.57 & 0.004 & 0.33 \\
Milk fat, $\mathrm{kg} / \mathrm{d}$ & 1.06 & 1.14 & 0.06 & 0.14 \\
Milk protein $(\mathrm{N} \times 6.38), \%$ & 3.12 & 3.08 & 0.001 & 0.31 \\
Milk protein $(\mathrm{N} \times 6.38), \mathrm{kg} / \mathrm{d}$ & 0.95 & 0.97 & 0.04 & 0.43 \\
Milk SNF, \% & 7.95 & 7.92 & 0.002 & 0.66 \\
Milk SNF, $\mathrm{kg} / \mathrm{d}$ & 2.46 & 2.55 & 0.23 & 0.38 \\
\hline
\end{tabular}

were not affected when 0.75 to $1.5 \%$ NaSC was added to the diet during short-term continuous or switch-over lactation experiments. In contrast to our findings, other researchers reported that milk fat percentage (PoosFloyd et al., 1985; Poos-Floyd and Coyle, 1986; Cassida et al., 1988; Ghorbani et al., 1989; Solorzano et al., 1989) and FCM yield (Jordan and Aguilar, 1985; PoosFloyd et al., 1985; Cassida et al., 1988; Ghorbani et al., 1989) either increased or tended to increase when 0.75 to $1.5 \%$ NaSC was added to the diet. Differences in results of those experiments caused by NaSC might be related to the composition of the diets, quantity of DM consumed, buffering capacity of the diet and its ability to stimulate saliva secretion, particle size of the diet (Clark and Davis, 1983) and the DCAD (Hu et al., 2007a). These results also are similar to those reported when $\mathrm{NaHCO}_{3}$ was utilized as a buffer in the diet. Positive responses for DMI, yields of milk and milk fat, and milk fat percentage were reported when cows were fed diets supplemented with $\mathrm{NaHCO}_{3}$ that contained corn silage as the primary source of forage (Erdman et al., 1980, 1982; Kilmer et al., 1980, 1981; Rogers et al., 1985). However, when alfalfa silage was included as a major part of the dietary forage, DMI and production of milk and milk components were not altered in many experiments (Donker and Marx, 1980, 1985; English et al., 1983; Boisclair et al., 1986) when $\mathrm{NaHCO}_{3}$ was added to the diet.

The addition of NaSC to the diet did not affect yields of milk, $4 \% \mathrm{FCM}$, fat, protein, and SNF; percentages of fat, protein, and SNF in milk; or BW and BCS during d 1 to 175 of lactation (Tables 3 and 4). However, visual appraisal of milk and 4\% FCM production curves (Figures 1 and 2) indicate that persistency during the 308-d lactation experiment was greatest for cows fed the diet that contained NaSC. This is supported by increased yields of milk, milk fat, and 4\% FCM during d 246 to 308 by cows fed NaSC (Table 4). However, the treatment by week interaction for milk or $4 \%$ FCM yields was not significant $(P>0.19)$. Still, cows fed the diet that contained NaSC produced $4.5 \mathrm{~kg}$ of milk/d more $(P<0.01)$ and $4.2 \mathrm{~kg}$ of $4 \% \mathrm{FCM} / \mathrm{d}$ more $(P<0.01)$ than control cows during d 246 to 308 of lactation.

During the later stages of lactation (d 176 to 308), addition of NaSC to the diet did not affect composition of milk (Table 4). The increase in milk yield with no change in milk fat percentage when cows were fed NaSC increased $(P<0.01)$ the yield of fat by $0.16 \mathrm{~kg} / \mathrm{d}$ during d 246 to 308. In addition, the increase in milk yield without an alteration of the protein and SNF content

Table 3. Least squares means for BW and BCS at various stages of a 308-d lactation for cows fed diets without (control) or with sodium sesquicarbonate (NaSC)

\begin{tabular}{|c|c|c|c|c|c|}
\hline \multirow[b]{2}{*}{ Item } & \multirow[b]{2}{*}{ Days of lactation } & \multicolumn{2}{|c|}{ Treatment } & \multirow[b]{2}{*}{ SEM } & \multirow[b]{2}{*}{$P<\mathrm{F}$} \\
\hline & & Control & $\mathrm{NaSC}$ & & \\
\hline \multirow[t]{4}{*}{$\mathrm{BW}, \mathrm{kg}$} & 1 to 308 & 673 & 642 & 16.3 & 0.12 \\
\hline & 1 to 175 & 650 & 626 & 16.1 & 0.22 \\
\hline & 176 to 245 & 689 & 651 & 17.6 & 0.09 \\
\hline & 246 to 308 & 722 & 674 & 18.1 & 0.04 \\
\hline \multirow[t]{4}{*}{$\mathrm{BCS}^{1}$} & 1 to 308 & 2.5 & 2.3 & 0.002 & 0.30 \\
\hline & 1 to 175 & 2.2 & 2.1 & 0.003 & 0.43 \\
\hline & 176 to 245 & 2.7 & 2.4 & 0.005 & 0.19 \\
\hline & 246 to 308 & 3.0 & 2.8 & 0.003 & 0.26 \\
\hline
\end{tabular}

${ }^{1} \mathrm{BCS} ; 1$ to 5 scale; $1=$ thin, $5=$ fat. 
Table 4. Least squares means for DMI, and milk production and composition at various stages of a 308-d lactation for cows fed diets without (control) or with sodium sesquicarbonate (NaSC)

\begin{tabular}{|c|c|c|c|c|c|}
\hline \multirow[b]{2}{*}{ Item } & \multirow[b]{2}{*}{ Days of lactation } & \multicolumn{2}{|c|}{ Treatment } & \multirow[b]{2}{*}{ SEM } & \multirow[b]{2}{*}{$P<\mathrm{F}$} \\
\hline & & Control & $\mathrm{NaSC}$ & & \\
\hline \multirow[t]{3}{*}{ DMI, $\mathrm{kg} / \mathrm{d}$} & 1 to 175 & 22.4 & 21.9 & 0.29 & 0.53 \\
\hline & 176 to 245 & 20.8 & 20.9 & 0.36 & 0.88 \\
\hline & 246 to 308 & 17.9 & 19.5 & 0.46 & 0.08 \\
\hline \multirow[t]{3}{*}{ DMI, $\%$ of BW } & 1 to 175 & 3.47 & 3.52 & 0.007 & 0.69 \\
\hline & 176 to 245 & 3.04 & 3.24 & 0.007 & 0.19 \\
\hline & 246 to 308 & 2.52 & 2.92 & 0.01 & 0.02 \\
\hline \multirow[t]{3}{*}{ Milk, kg/d } & 1 to 175 & 38.0 & 37.9 & 0.43 & 0.98 \\
\hline & 176 to 245 & 26.3 & 27.9 & 0.35 & 0.33 \\
\hline & 246 to 308 & 16.7 & 21.2 & 1.82 & 0.01 \\
\hline \multirow[t]{3}{*}{$4 \% \mathrm{FCM}, \mathrm{kg} / \mathrm{d}$} & 1 to 175 & 34.6 & 35.3 & 0.32 & 0.59 \\
\hline & 176 to 245 & 23.3 & 25.1 & 0.26 & 0.21 \\
\hline & 246 to 308 & 16.2 & 20.4 & 1.53 & 0.01 \\
\hline \multirow[t]{3}{*}{ Milk fat, $\%$} & 1 to 175 & 3.44 & 3.58 & 0.007 & 0.16 \\
\hline & 176 to 245 & 3.28 & 3.37 & 0.006 & 0.47 \\
\hline & 246 to 308 & 3.82 & 3.76 & 0.006 & 0.59 \\
\hline \multirow[t]{3}{*}{ Milk fat, $\mathrm{kg} / \mathrm{d}$} & 1 to 175 & 1.29 & 1.34 & 0.09 & 0.40 \\
\hline & 176 to 245 & 0.85 & 0.93 & 0.05 & 0.17 \\
\hline & 246 to 308 & 0.63 & 0.79 & 0.09 & 0.01 \\
\hline \multirow[t]{3}{*}{ Milk protein $(\mathrm{N} \times 6.38), \%$} & 1 to 175 & 2.99 & 2.95 & 0.001 & 0.39 \\
\hline & 176 to 245 & 3.17 & 3.15 & 0.001 & 0.70 \\
\hline & 246 to 308 & 3.44 & 3.34 & 0.001 & 0.18 \\
\hline \multirow[t]{3}{*}{ Milk protein $(\mathrm{N} \times 6.38), \mathrm{kg} / \mathrm{d}$} & 1 to 175 & 1.12 & 1.11 & 0.04 & 0.74 \\
\hline & 176 to 245 & 0.83 & 0.87 & 0.04 & 0.33 \\
\hline & 246 to 308 & 0.57 & 0.71 & 0.10 & 0.01 \\
\hline \multirow{3}{*}{ Milk SNF, \% } & 1 to 175 & 7.91 & 7.92 & 0.002 & 0.91 \\
\hline & 176 to 245 & 7.91 & 7.86 & 0.003 & 0.44 \\
\hline & 246 to 308 & 8.09 & 7.99 & 0.004 & 0.27 \\
\hline \multirow[t]{3}{*}{ Milk SNF, $\mathrm{kg} / \mathrm{d}$} & 1 to 175 & 2.99 & 2.99 & 0.28 & 0.99 \\
\hline & 176 to 245 & 2.08 & 2.18 & 0.24 & 0.40 \\
\hline & 246 to 308 & 1.35 & 1.69 & 0.71 & 0.01 \\
\hline
\end{tabular}

of milk when cows were fed NaSC increased $(P<0.01)$ protein (by $0.14 \mathrm{~kg} / \mathrm{d})$ and increased $(P<0.01) \mathrm{SNF}$ (by $0.34 \mathrm{~kg} / \mathrm{d}$ ) during d 246 to 308 of lactation. There was a treatment by week interaction for percentage of milk protein $(P<0.001)$ and a trend for the interaction in percentage of SNF $(P<0.09)$. However, visual appraisal of the graphs of weekly means (Figures 3 and 4) do not provide any indication that treatments were having profound effects on milk composition. There was also a treatment by week interaction for SNF yield $(P<0.06)$. The graph of weekly mean SNF yields (Figure 5) indicates that the interaction was probably due to increased SNF yield during late lactation in cows fed the NaSC diet compared with cows fed the control diets. This is supported by an increased mean yield of SNF during d 246 to 308 for cows fed NaSC compared with cows fed the control diet (Table 4).

In another 308-d lactation experiment (Tucker et al., 1994), cows were fed diets that contained $13.1 \%$ alfalfa hay, $17.6 \%$ sorghum silage, $7.9 \%$ whole cottonseed, and $61.3 \%$ concentrate with $(1 \%)$ or without NaSC. Our data agree with the findings of Tucker et al. (1994) who reported that the percentage of fat in milk was not altered by NaSC during early or midlactation; however,
Tucker et al. (1994) reported that milk fat percentage was increased in later lactation and that milk protein percentage was increased during the complete lactation, which was not observed in our experiment. We also observed an increase in milk yield during late lactation that was not observed by Tucker et al. (1994).

Addition of NaSC to the diet did not affect DMI (Table 4; Figure 6) or DMI as a percentage of BW during $\mathrm{d} 1$ to 175 or $\mathrm{d} 176$ to 245 but tended $(P<0.08)$ to increase DMI and increased DMI as a percentage of BW $(P<0.02)$ during d 246 to 308 when the higher forage diet was fed to the cows, which may explain a portion of the increase in yield of milk and milk components during that time. These data agree with the findings of Tucker et al. (1994) when diets were formulated to provide sufficient fiber of adequate particle size.

The BW of control cows (Table 3 ) was greater during d 246 to $308(P<0.04)$ and tended to be greater during d 176 to $245(P<0.09)$. This greater BW is reflected in the slightly higher, although nonsignificant, BCS observed for control cows during these periods (Table 3 ). The difference in BW between cows that consumed control and NaSC-containing diets might be explained by the slightly lower but nonsignificant difference in BW 


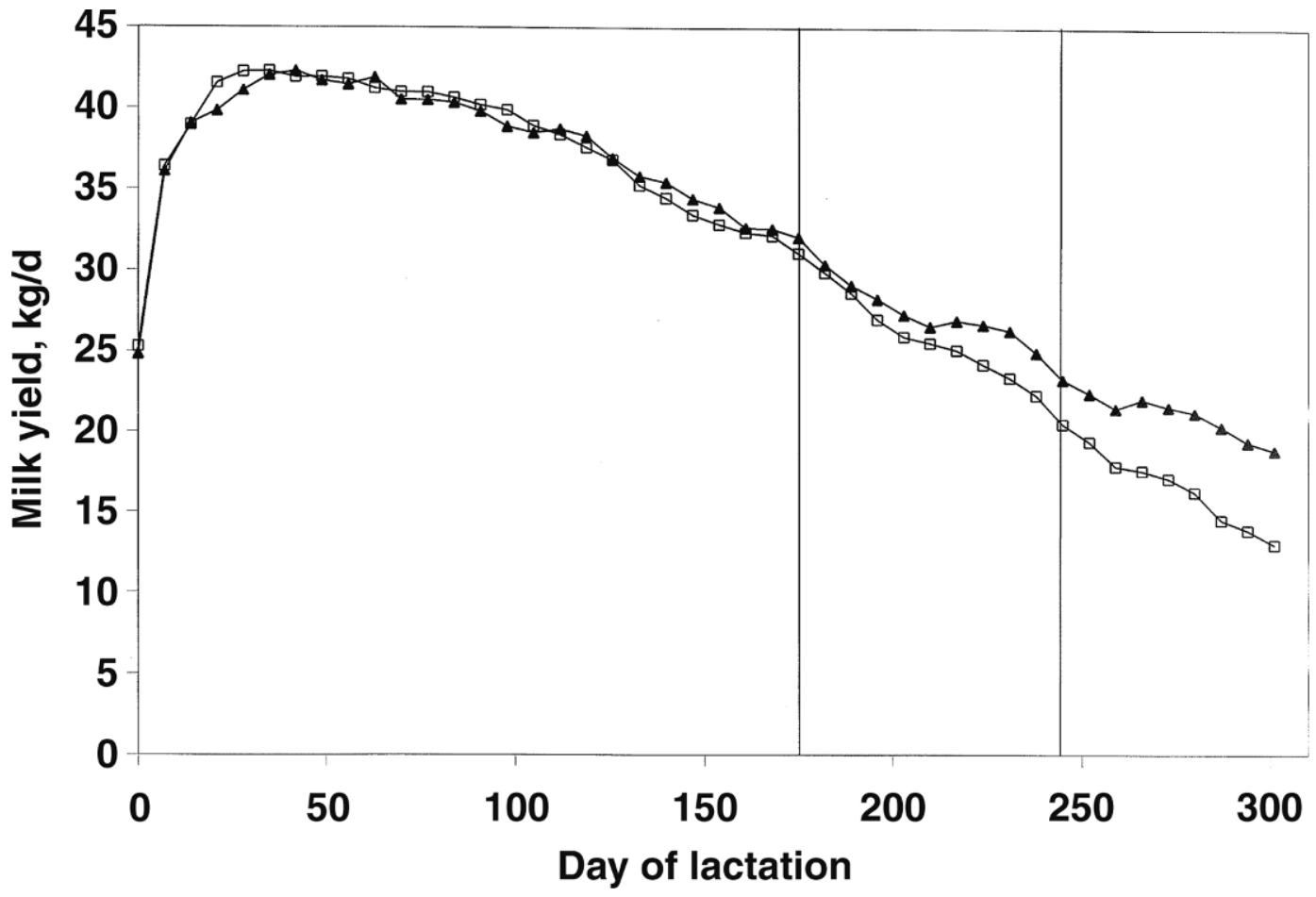

Figure 1. Effects of control ( $\square$ ) or sodium sesquicarbonate $(\mathbf{\Lambda})$ on yields of milk during d 1 to 175 (SEM 0.43 ), d 176 to 245 (SEM 0.35 ), and d 246 to 308 (SEM 1.82) of a 308-d lactation trial.

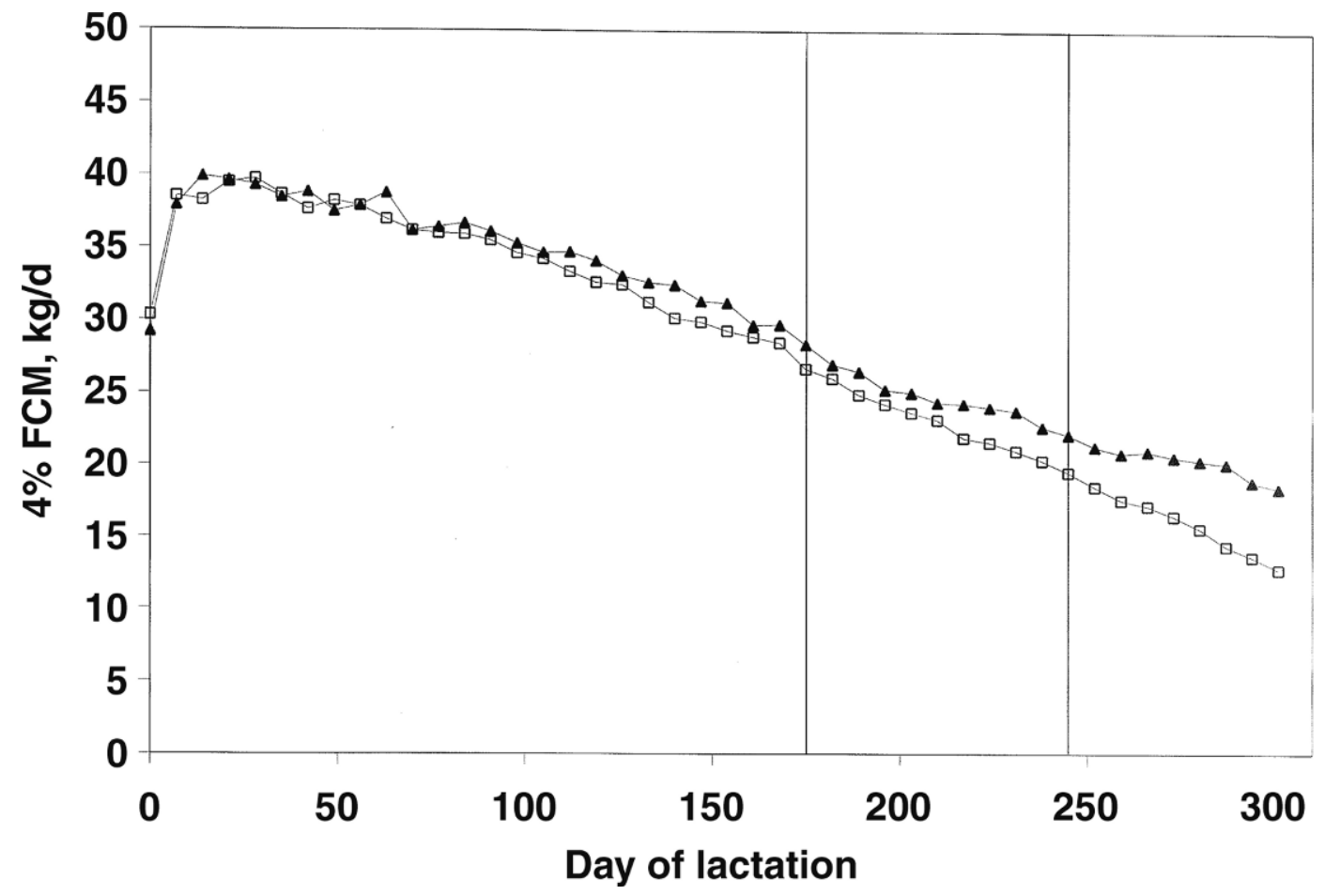

Figure 2. Effects of control ( $\square$ ) or sodium sesquicarbonate ( $\mathbf{\Delta}$ ) on 4\% FCM yields during d 1 to 175 (SEM 0.32), d 176 to 245 (SEM 0.26 ), and d 246 to 308 (SEM 1.53) of a 308-d lactation trial. 


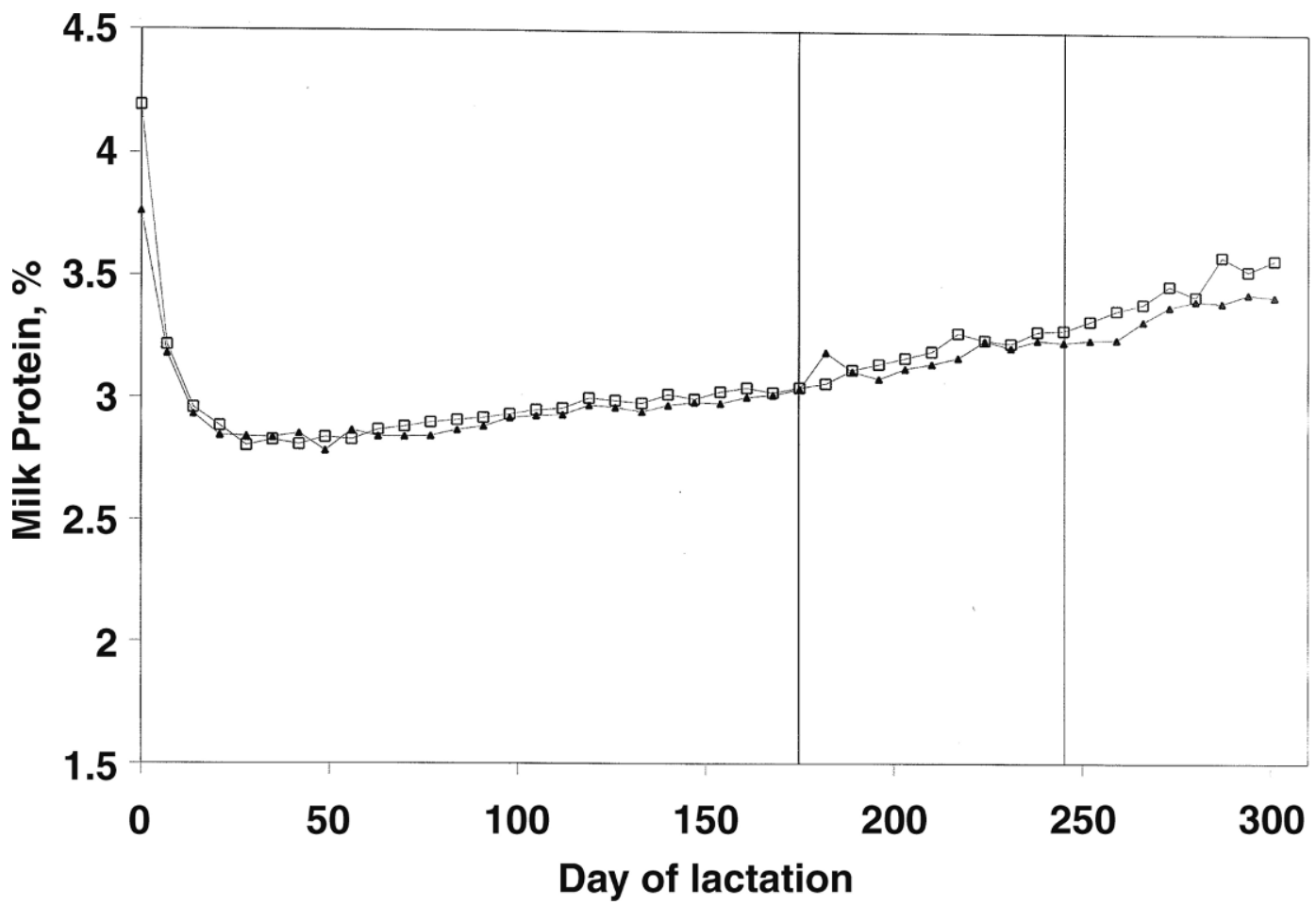

Figure 3. Effects of control $(\square)$ or sodium sesquicarbonate $(\boldsymbol{\Lambda})$ on milk protein percentage during d 1 to 175 (SEM 0.001 ), d 176 to 245 (SEM 0.001), and d 246 to 308 (SEM 0.001) of a 308-d lactation trial.

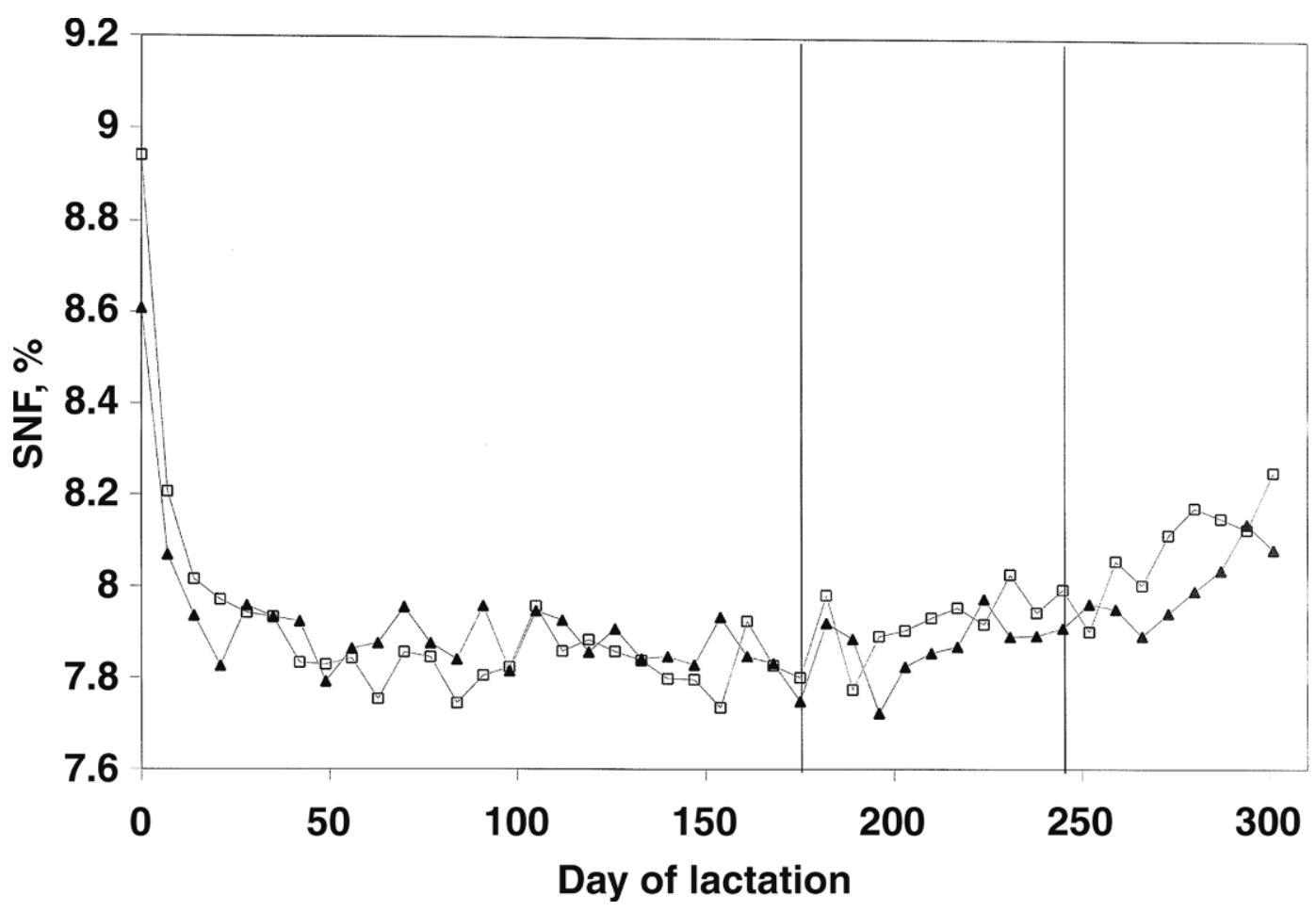

Figure 4. Effects of control $(\square)$ or sodium sesquicarbonate ( $\mathbf{\Delta}$ ) on SNF percentage during d 1 to 175 (SEM 0.002), d 176 to 245 (SEM 0.003 ), and d 246 to 308 (SEM 0.004) of a 308-d lactation trial. 


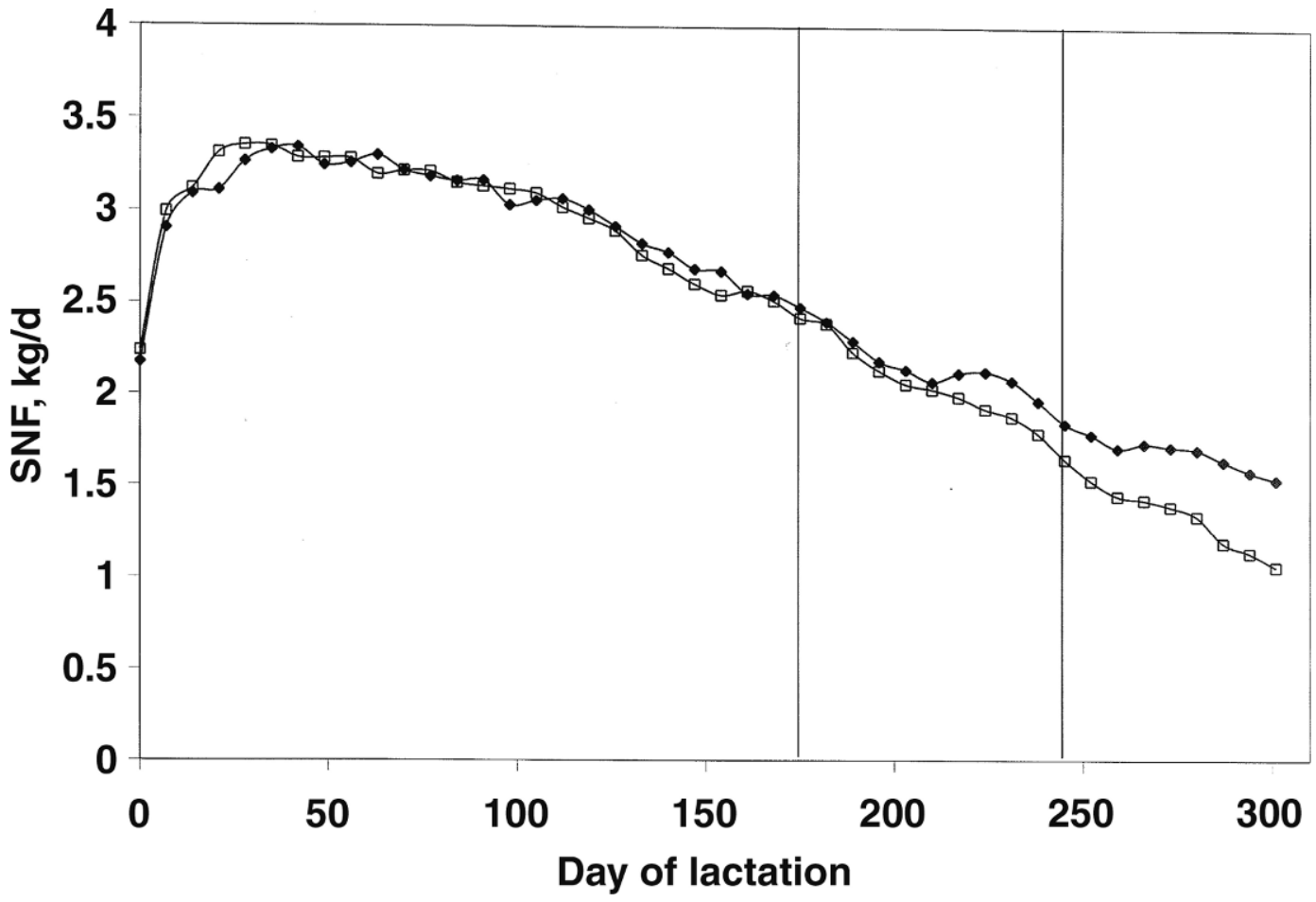

Figure 5. Effects of control $(\square)$ or sodium sesquicarbonate ( ) on SNF yields during d 1 to 175 (SEM 0.28), d 176 to 245 (SEM 0.24), and d 246 to 308 (SEM 0.71) of a 308-d lactation trial.

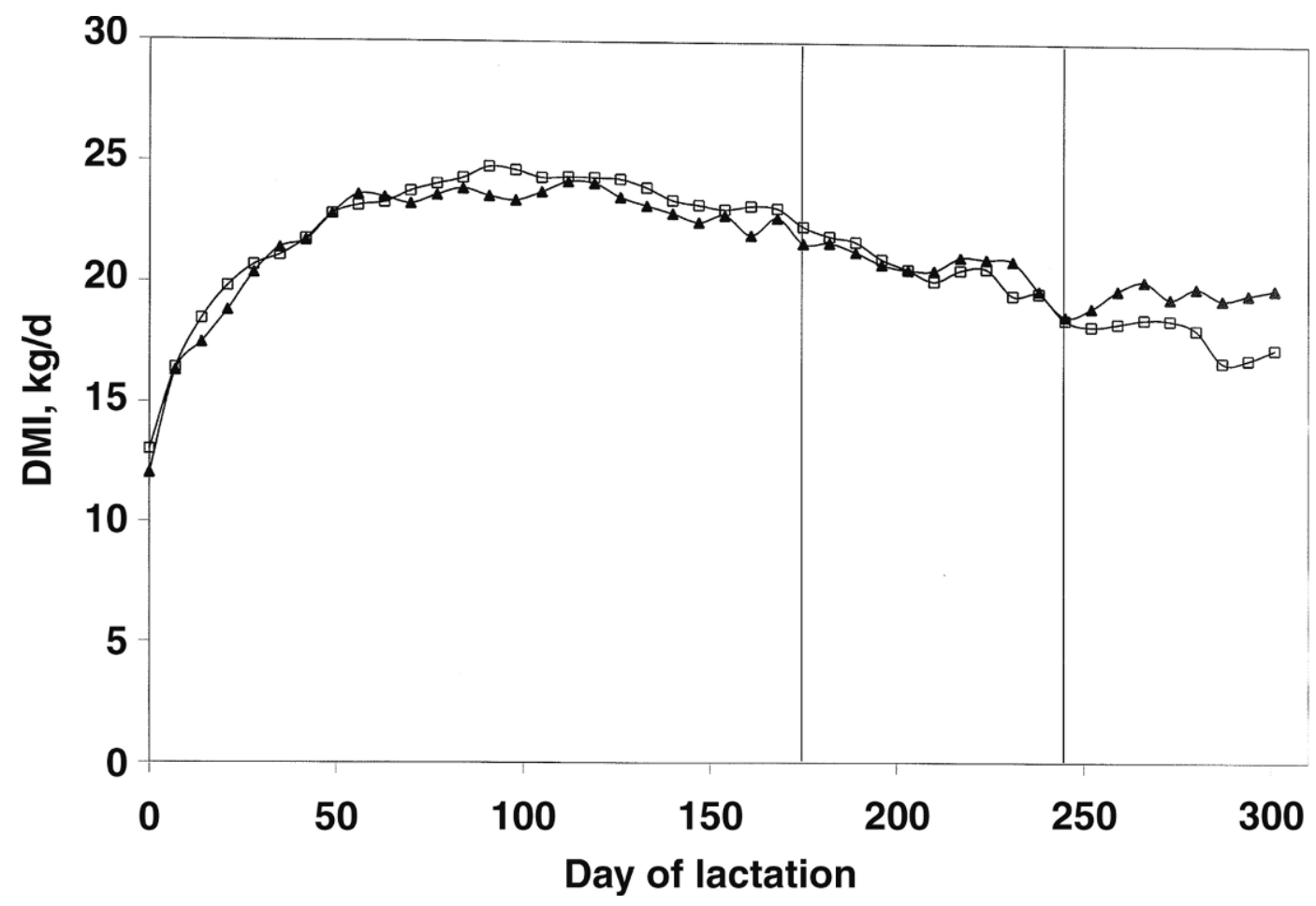

Figure 6. Effects of control ( $\square$ ) or sodium sesquicarbonate ( $\mathbf{\Delta}$ ) on DMI during d 1 to 175 (SEM 0.29), d 176 to 245 (SEM 0.36 ), and d 246 to 308 (SEM 0.46) of a 308-d lactation trial. 
at the beginning of the trial; the greater yields of milk and $4 \%$ FCM; more nutrients being utilized for milk production than for body tissue synthesis; or a greater number of days open for cows fed the diet with NaSC. To determine whether the increased yields of milk and milk components in the later stages of lactation were truly because of the NaSC in the diet or because of the absence of pregnancy, which allowed more nutrients to be partitioned for milk production rather than growth of the conceptus, data for the complete 308-d lactation experiment were subjected to analysis of covariance using the number of days open as a covariate. Number of days open was found to be nonsignificant as a covariate and was dropped from further analysis.

These data indicate that NaSC increased the yields of milk and milk components near the end of lactation when cows were fed a higher forage diet that contained $0.8 \%$ NaSC on a DM basis. Traditionally, the greatest benefits of dietary buffers have been observed when low fiber diets were fed in large amounts to high-producing cows (Erdman, 1988; Hu and Murphy, 2005). The role of buffers in the diet of lactating dairy cows is thought to be the prevention of digestive upsets, metabolic disorders, milk fat depression, and regulation of acidbase balance that might result when cows are fed high concentrate, low fiber diets, especially during early lactation. To date, the addition of NaSC to the diet has resulted in positive responses in productivity mostly when diets contain large amounts of concentrate and small amounts of fiber.

One explanation for these results when NaSC was fed might be the composition of the diets utilized during the various stages of this lactation experiment. The diet fed from d 1 to 175 contained less forage than did the diet fed from d 246 to 308 ; however, the diet fed during d 1 to 175 contained more RUP and fat than did diets fed later in lactation. Diets were altered throughout the lactation by replacing RUP and fat with ground shelled corn during d 176 to 245 and with forage during d 246 to 308 . As diets were altered to supply more potentially digestible organic matter in the rumen, milk production by cows fed diets that contained NaSC began to increase but did not attain significance during d 176 to 245 of lactation (Figure 1). However, during d 246 to 308 the increase in milk production was greater for cows fed the diet that contained NaSC. These changes in the composition of the diet might have increased the proportion of $\mathrm{OM}$ digested in the rumen of cows fed NaSC during d 246 to 308 compared with ruminal digestibility of $\mathrm{OM}$ during $\mathrm{d} 1$ to 175 or $\mathrm{d} 176$ to 245. As has been shown for $\mathrm{NaHCO}_{3}$, the presence of NaSC in the diet during d 246 to 308 might have increased passage of soluble nutrients in ruminal fluid to the small intestine (Mees et al., 1985) and stabilized ruminal $\mathrm{pH}$ and fermentation (Davis, 1979; Rogers et al., 1979, 1982), thereby promoting greater digestibility of OM and increased DMI, which increased production of milk and milk components. Likewise, addition of NaSC to the diet of male buffaloes increased ruminal $\mathrm{pH}$, ruminal fluid outflow, and dry matter disappearance from nylon bags suspended in the rumen (Puri and Kapoor, 1996).

Erdman et al. (1982) suggested that feeding buffers such as $\mathrm{NaHCO}_{3}$ to dairy cows might not increase ruminal fluid dilution rate when fed at recommended concentrations of up to $1.0 \%$ of the dietary DM. Okeke et al. (1983) reported that ruminal fluid dilution rate was greater when steers were fed diets that contained 2.5 or $5.0 \%$ buffer than was ruminal fluid dilution rate for steers fed diets that contained 0 or $0.75 \%$ buffer. However, the addition of buffer at $0.75,2.5$, or $5.0 \%$ of the dietary DM resulted in linear increases in ruminal fluid dilution rates. This suggests that dilution rate is probably increased at lower levels of feeding but not as much as at higher levels of feeding.

Another explanation for increases in production of milk and milk components obtained in this experiment during d 246 to 308 might be the potential effect of $\mathrm{NaSC}$ on the DCAD of diets fed to the cows. Previous experiments ( $\mathrm{Hu}$ et al., 2007a) indicate that $\mathrm{NaHCO}_{3}$ increased DCAD and that DCAD and production by dairy cows are related. It appears that the DCAD of the diet affects acid-base balance regulation, which in turn affects DMI of dairy cows when $\mathrm{NaHCO}_{3}$ is added to the diet (Hu et al., 2007a, b). The DMI and DMI as a percentage of BW of cows were increased during d 246 to 308 of lactation in our experiment (Table 4). If NaSC altered DCAD and improved acid-base balance, which increased DMI, this might explain a part of the increase in production of milk and milk components. Because ruminal fermentation, digestion of OM, and mineral analyses were not measured in our experiment, the exact mechanism by which NaSC increased production of milk and milk components in the later stages of lactation is not known.

\section{CONCLUSIONS}

Feeding NaSC to lactating cows increased the yields of milk, $4 \% \mathrm{FCM}$, and components in milk during late lactation when feeds that normally have a lower ruminal digestibility were replaced in the diet with feeds that normally have a higher ruminal digestibility. Beneficial effects of the dietary buffer were more pronounced in late lactation, which might have been the result of increased digestibility of $\mathrm{OM}$ or an improved DCAD of diets fed to the cows. These data suggest that composition of the diet has a significant effect on the responses to dietary buffers by lactating dairy cows. 


\section{ACKNOWLEDGMENTS}

The authors thank Church \& Dwight Company Inc. for providing the NaSC, Ca salts of long-chain fatty acids, and partial financial support for this experiment, and M. R. Cameron (Department of Animal Sciences, University of Illinois) for work in conducting this experiment.

\section{REFERENCES}

Aguilar, A. A., and D. C. Jordan. 1985. Addition of sodium sesquicarbonate at various levels in complete mixed rations for early postpartum dairy cows. J. Dairy Sci. 68(Suppl. 1):137. (Abstr.)

AOAC. 2002. Official Methods of Analysis. Vol. I. 17th ed. Association of Official Analytical Chemists, Arlington, VA.

Boisclair, Y., D. G. Grieve, J. B. Stone, O. B. Allen, and G. K. Macleod. 1986. Effect of prepartum energy, body condition, and sodium bicarbonate on production of cows in early lactation. J. Dairy Sci. 69:2636-2647.

Cassida, K. A., L. D. Muller, and T. F. Sweeney. 1988. Sodium sesquicarbonate for early lactation dairy cows fed corn silage-based diets. J. Dairy Sci. 71:381-387.

Clark, J. H., and C. L. Davis. 1983. Response of dairy cattle to buffers. In Buffers, Neutralizers and Electrolytes Symp. Minneapolis, MN Natl. Feed Ingredients Assoc., West Des Moines, IA.

Coppock, C. E., G. T. Schelling, F. M. Byers, J. W. West, and J. M. Labore. 1986. A naturally occurring mineral as a buffer in the diet of lactating dairy cows. J. Dairy Sci. 69:111-123.

Davis, C. L. 1979. The use of buffers in the rations of lactating dairy cows. Pages 51-64 in Regulation of Acid-Base Balance. W. H. Hale and P. Meinhardt, ed. Church \& Dwight Company Inc., Piscataway, NJ.

Donker, J. D., and G. D. Marx. 1980. Sodium bicarbonate in diets for milking Holstein cows. J. Dairy Sci. 63:931-935.

Donker, J. D., and G. D. Marx. 1985. Dietary sodium bicarbonate for high-producing Holstein cows over complete lactations. J. Dairy Sci. $68: 140-146$

English, J. E., T. J. Fronk, D. G. Braund, and J. E. Nocek. 1983. Influence of buffering early lactation rations with sodium bicarbonate and magnesium oxide and subsequent withdrawal or addition effects. J. Dairy Sci. 66:505-513.

Erdman, R. A. 1988. Dietary buffering requirements of the lactating dairy cow: A review. J. Dairy Sci. 71:3246-3266.

Erdman, R. A., R. L. Botts, R. W. Hemken, and L. S. Bull. 1980. Effect of dietary sodium bicarbonate and magnesium oxide on production and physiology in early lactation. J. Dairy Sci. 63:923-930.

Erdman, R. A., R. W. Hemken, and L. S. Bull. 1982. Dietary sodium bicarbonate and magnesium oxide for early postpartum lactating dairy cows: Effects on production, acid-base metabolism, and digestion. J. Dairy Sci. 65:712-731.

Ghorbani, G. R., J. A. Jackson, and R. W. Hemken. 1989. Effects of sodium bicarbonate and sodium sesquicarbonate on animal performance, ruminal metabolism, and systemic acid-base status. J. Dairy Sci. 72:2039-2045.

Golding, N. S. 1959. A solids-not-fat test for milk using density plastic beads as hydrometers. J. Dairy Sci. 42:899. (Abstr.)

Hu, W., L. Kung Jr., and M. R. Murphy. 2007a. Relationships between dry matter intake and acid-base status of lactating dairy cows as manipulated by dietary cation-anion difference. Anim. Feed Sci. Technol. 136:216-225.
Hu, W., and M. R. Murphy. 2005. Statistical evaluation of early- and mid-lactation dairy cow responses to dietary sodium bicarbonate addition. Anim. Feed Sci. Technol. 199:43-54.

Hu, W., M. R. Murphy, P. D. Constable, and E. Block. 2007b. Dietary cation-anion difference and dietary protein effects on performance and acid-base status of dairy cows in early lactation. J. Dairy Sci 90:3355-3366.

Jordan, D. C., and A. A. Aguilar. 1985. Sodium sesquicarbonate for lactating cows. J. Dairy Sci. 68(Suppl. 1):137-138. (Abstr.)

Kilmer, L. H., L. D. Muller, and T. J. Snyder. 1981. Addition of sodium bicarbonate to rations of postpartum dairy cows: Physiological and metabolic effects. J. Dairy Sci. 64:2357-2369.

Kilmer, L. H., L. D. Muller, and P. J. Wangsness. 1980. Addition of sodium bicarbonate to rations of pre- and postpartum dairy cows. J. Dairy Sci. 63:2026-2036.

Littell, R. C., G. A. Milliken, W. W. Strong, and R. D. Wolfginger. 1996. SAS System for Mixed Models. SAS Institute Inc., Cary, $\mathrm{NC}$

Mees, D. C., N. R. Merchen, and C. J. Mitchel. 1985. Effects of sodium bicarbonate on nitrogen balance, bacterial protein synthesis, and sites of nutrient digestion in sheep. J. Anim. Sci. 61:985-994

National Research Council. 1989. Nutrient Requirements of Dairy Cattle. 6th rev. ed. Natl. Acad. Sci., Washington, DC.

Okeke, G. C., J. G. Buchanan-Smith, and W. L. Grovum. 1983. Effects of buffers on ruminal rate of passage and degradation of soybean meal in steers. J. Anim. Sci. 56:1393-1399.

Poos-Floyd, M., and C. A. Coyle. 1986. Effect of level of sodium sesquicarbonate on production and rumen parameters of lactating Holstein cows. J. Dairy Sci. 69(Suppl. 1):241. (Abstr.)

Poos-Floyd, M., K. L. Snow, and D. W. Johnson. 1985. Evaluation of sodium sesquicarbonate vs sodium bicarbonate for dairy cows fed corn silage based diets in early lactation. J. Dairy Sci. 68(Suppl. 1):277-288. (Abstr.)

Puri, J. P., and P. D. Kapoor. 1996. Response of sodium bicarbonate and sodium sesquicarbonate as buffering agents on rumen metabolites and water kinetics in buffalo. Indian J. Anim. Sci. 66:285-290.

Rogers, J. A., C. L. Davis, and J. H. Clark. 1982. Alteration of rumen fermentation, milk fat synthesis, and nutrient utilization with mineral salts in dairy cows. J. Dairy Sci. 65:577-586.

Rogers, J. A., B. C. Marks, C. L. Davis, and J. H. Clark. 1979. Alteration of rumen fermentation in steers by increasing rumen fluid dilution rate with mineral salts. J. Dairy Sci. 62:1599-1605.

Rogers, J. A., L. D. Muller, C. L. Davis, W. Chalupa, D. S. Kronfeld, L. F. Karcher, and K. R. Cummings. 1985. Response of dairy cows to sodium bicarbonate and limestone in early lactation. J. Dairy Sci. 68:646-660.

Solorzano, L. C., L. E. Armentano, R. R. Grummer, and M. R. Dentine. 1989. Effects of sodium bicarbonate or sodium sesquicarbonate on lactating Holsteins fed a high grain diet. J. Dairy Sci. 72:453461

Tucker, W. B., I. S. Shin, J. F. Hogue, M. Aslam, G. D. Adams, M. T. Van Koevering, R. K. Vernon, and K. R. Cummings. 1994. Natural sodium sesquicarbonate fed for an entire lactation: Influence on performance and acid-base status of dairy cows. J. Dairy Sci. 77:3111-3117.

Van Soest, P. J., J. B. Robertson, and B. A. Lewis. 1991. Methods for dietary fiber, neutral detergent fiber, and nonstarch polysaccharides in relation to animal nutrition. J. Dairy Sci. 74:3583-3597.

Wildman, E. E., G. M. Jones, P. E. Wagner, R. L. Boman, H. F. Troutt Jr., and T. N. Lesch. 1982. A dairy cow body condition scoring system and its relationship to selected production characteristics. J. Dairy Sci. 65:495-501. 